\title{
Cholesterol content in eggs produced by hens divergently selected for body weight (Short Communication)
}

\author{
DUŠAN TERČIČ, ALENKA LEVART and ANTONIJA HOLCMAN
}

University of Ljubljana, Biotechnical Faculty, Department of Animal Science, Slovenia

\begin{abstract}
In this work the cholesterol content of chicken eggs produced by two lines (high and low weight) representing the 31st generation of selection for divergent growth was studied. Divergent selection for body weight at 8 weeks of age resulted in changes in egg size and consequently in the weight of egg components. Higher values $(P \leq 0.001)$ were observed in eggs from the high weight $(D+)$ line for egg weight, albumen, yolk and shell weight. Percent yolk was greater $(P \leq 0.001)$ and percent albumen was lower $(P \leq 0.001)$ in eggs from the low weight $(D-)$ line. Eggs from the $D-$ line contained lower $(P \leq 0.001)$ cholesterol content $(\mathrm{mg} /$ egg, $\mathrm{mg} / \mathrm{g}$ yolk, $\mathrm{mg} / \mathrm{g}$ yolk dry matter) than eggs from the $D+$ line but when cholesterol was expressed in milligrams per gram of egg or per gram of edible egg, differences between the two lines were not significant. Divergent selection for body weight changed the albumen:yolk ratio and a change of this type affected the grams of cholesterol per gram of yolk values.
\end{abstract}

Keywords: hen, two-way selection, body weight, egg traits, cholesterol

\section{Zusammenfassung}

\section{Cholesteringehalt in Hühnereiern von Hennen, die auf unterschiedliches Körpergewicht selektiert wurden (Kurzmitteilung)}

Untersucht wurde der Cholesteringehalt von Eiern von Hennen welche in 31 Generationen auf unterschiedliche Acht-Wochen Körpergewichte ( $D+$ hohes, $D$ - niedriges Körpergewicht) selektiert wurden. Bewertet wurden Eigewicht, innere Eiqualitätsmerkmale sowie der Cholesteringehalt. Signifikant höhere Werte ergaben sich für die D+ Gruppe bei Ei- EiweißEigelb- und Schalengewichten. Ein signifikant höherer Eigelbanteil verbunden mit einem kleineren Eiweißanteil fand sich bei den D- Tieren. D- Tiere wiesen einen geringeren Cholesteringehalt ( $\mathrm{mg} / \mathrm{Ei}, \mathrm{mg} /$ Eigelb, $\mathrm{mg} /$ Eigelbtrockenmasse) als D+ Tiere auf jedoch waren diese Unterschiede bezüglich Cholesterin in $\mathrm{mg}$ bezogen auf $\mathrm{g}$ des genießbaren Eies nicht signifikant. Eine unterschiedliche Selektion auf Körpergewicht veränderte das Eiweiß: Eigelb Verhältnis und diese Veränderung beeinflusste den Cholesterinanteil im Eigelb.

Schlüsselwörter: Huhn, Langzeitselektion, Körpergewicht, Eimerkmale, Cholesterin 


\section{Introduction}

Dietary cholesterol, chiefly in the form of eggs, has long been outlawed as a causative agent in coronary heart disease through its association with serum cholesterol (LEE and GRIFFIN 2006). McNAMARA (2000) who reviewed 30 years of cholesterol research, found that dietary cholesterol has a relatively small effect on plasma total cholesterol and that egg consumption, specifically, has little relationship to high blood cholesterol or incidence of heart disease. In fact recent studies (e.g. KRITCHEVSKY and KRITCHEVSKY 2000, KATZ et al. 2005, LEE and GRIFFIN 2006, QURESHI et al. 2007) have demonstrated that healthy adults can enjoy one or two eggs a day without any effect on their risk for heart disease. PFEUFFER (2001) reported that the major impact on plasma cholesterol levels is probably exerted via dietary fatty acids. Several studies have focused on the effect of egg consumption on the LDL:HDL ratio and the total: HDL ratio as indicators of heart disease risk. According to WEGGEMANS et al. (2001), dietary cholesterol raises the ratio of total to HDL cholesterol and, therefore, adversely affects the cholesterol profile. The advice to limit cholesterol intake by reducing consumption of eggs and other cholesterol-rich foods may therefore still be valid. Cholesterol from the egg comes exclusively from the egg yolk. Although many factors including genetic selection (HARGIS 1988), breed or strain (SAINZ et al. 1983), avian species (STRAKOVA et al. 2001), age of fowl (JIANG and SIM 1991) and dietary manipulations (KOVACS et al. 2000) influence egg yolk cholesterol concentrations, the effects of long-term divergent selection for body weight on egg yolk cholesterol have not been examined. This prompted us to perform the present study.

\section{Material and methods}

\section{Birds and housing}

A divergent selection experiment with chickens, using body weight at 8 weeks of age (BW at $8 \mathrm{wk}$ ) as the selection criterion, was undertaken for 31 generations. The main purpose of the experiment was to determine the genetic effects of divergent selection for BW at 8 wk over successive generations and to analyze the occurrence of correlated responses in unselected traits. In generation 31, BW at 8 wk of age in the high weight (D+) line was seven and half times that of the low weight (D-) line. The evolution of the phenotypic generation least squares means (LSM) of BW at 8 wk in two experimental lines is presented in the Figure. Both growth-selected lines were reared together in a windowless house on deep litter system up to the age of $8 \mathrm{wk}$. Afterwards, selected parents of each line were reared in separate pens within the same poultry house. During the laying period standard laying ration (2 $716 \mathrm{kcal}$ $\mathrm{ME} / \mathrm{kg}, 16.2 \% \mathrm{CP}$ ) was fed to both lines. Feed and water were supplied ad libitum.

\section{Determination of cholesterol concentration in yolks}

In generation 31, ten eggs laid on the day of collection were randomly sampled from each line when the hens were 49 wk old. All yolks were carefully separated from the albumen, weighed, mixed thoroughly and freeze-dried. After freeze-drying they were weighed, homogenized, vacuum packed in plastic bags and stored at $-20^{\circ} \mathrm{C}$ prior to analysis. Yolk dry 
matter (DM) determination was performed on 3 to $5 \mathrm{~g}$ samples. They were weighed before and after drying to constant weight at $103^{\circ} \mathrm{C}$. Yolk cholesterol concentrations were measured with enzymatic colorimetric tests (BOEHRINGER Mannheim GmbH, Mannheim, Germany 1987). Briefly, the method is based on oxidation by cholesterol oxidase with the liberation of hydrogen peroxide which then oxidizes methanol to formaldehyde in the presence of catalase. The formaldehyde subsequently reacts with ammonia and acetylacetone to form a stable lutidine derivative, which was determined colorimetrically at $405 \mathrm{~nm}$. All samples were analysed in duplicate. The control material used for checking accuracy of the method was a whole egg powder SRM 1845 (National Institute of Standards and Technology 1989) with a certified cholesterol concentration of $19.0 \pm 0.2 \mathrm{mg} / \mathrm{g}$.

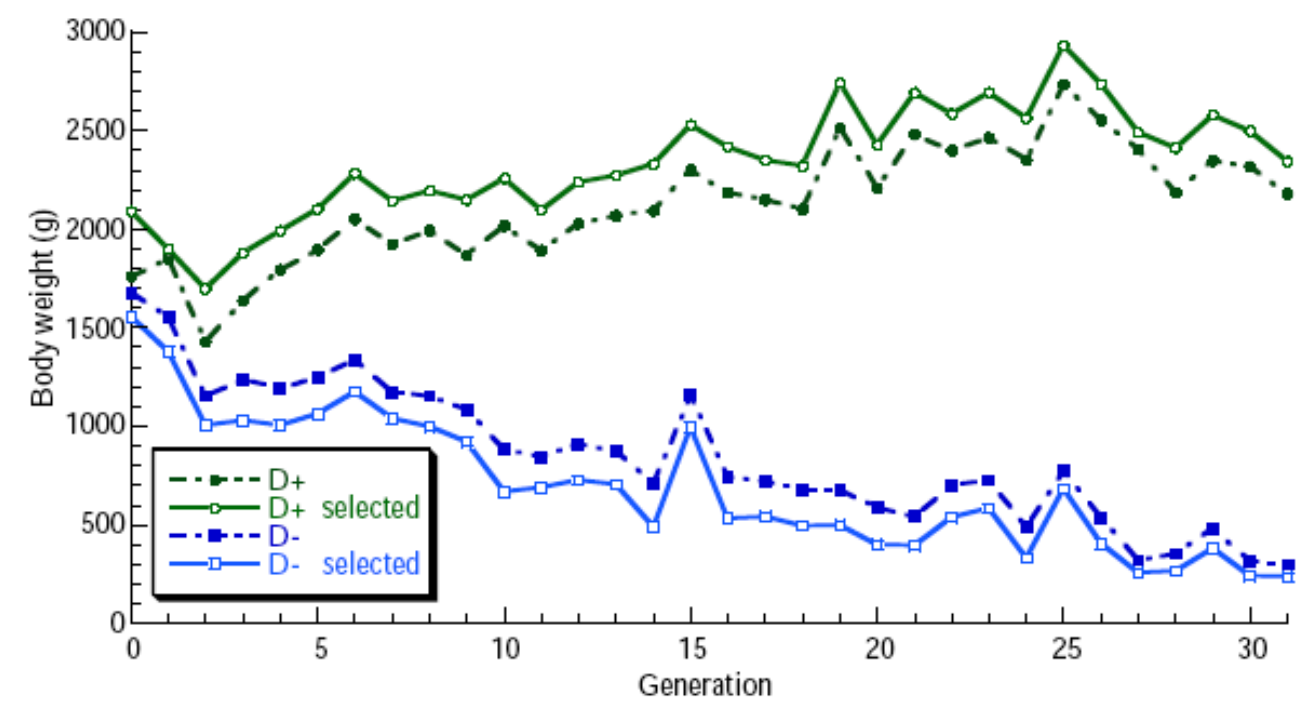

Figure

LSM for BW at 8 wk of age in both lines across generations. $D+=$ high weight line; $D-=$ low weight line; $D+$ selected, $D-$ selected=animals selected to be parents of the next generation in $D+$ and $D-$ line, respectively LSQMittelwerte für 8-Wochen Körpergewicht in 31 Generationen der D+ (größere) und D-(kleinere Körpergewichte) Linie

\section{Statistical analysis}

To analyse repeated measures the restricted maximum likelihood method (REML), the default in SAS PROC MIXED, was used (SAS Institute 2001). Yolk cholesterol data were analysed by the following model:

$$
y_{i j}=\mu+L_{i}+e_{i j}
$$

where $y_{i j}$ was the measurement for the $j$-th egg yolk within the i-th line, $\mu$ is the common mean, $L_{i}$ is the effect of the $i$-th line, and $e_{i j}$ is random error. 


\section{Results}

The composition of the eggs from the two lines studied is shown in Table 1. Differences were significant between lines for egg weight, albumen weight, yolk weight, shell weight, percentagealbumen, percentageyolk, percentage shelland Y (yolk) : A (albumen) ratio(Table 1). Egg, albumen, yolk and shell weights of the $D+$ line were greater $(P \leq 0.001)$ compared to the $D$ - line. Eggs of the $D$ - line showed higher shell $(P \leq 0.01)$ and yolk $(P \leq 0.001)$ proportion, lower albumen percentage $(P \leq 0.001)$ and higher $Y$ : A ratio $(P \leq 0.001)$ than eggs of the $D+$ line (Table 1). Analytical data was calculated both on the basis of milligrams of cholesterol per egg and on the basis of milligrams of cholesterol per gram of egg, edible egg (yolk+albumen), yolk and yolk DM to eliminate the effect of different egg sizes. Mean cholesterol values are given in Table 2. Least square mean (LSM) cholesterol values were 341.47 and $212.37 \mathrm{mg} / \mathrm{egg}$ for the $D+$ and $D-$ lines, respectively.

Table 1

Least square mean values and standard errors ( $L S M \pm S E$ ) for different egg traits in $D+$ and $D-$ lines LSQ Mittelwerte \pm Standardfehler der Eimerkmale für D+ und D-Linien

\begin{tabular}{lccc}
\hline Trait & Number of measurements & Line \\
& & High weight, D+ & Low weight, D- \\
\hline Egg weight, g & 10 & $77.24 \pm 1.14^{* * *}$ & $48.42 \pm 1.14$ \\
Albumen weight, g & 10 & $47.41 \pm 0.87^{* * *}$ & $27.20 \pm 0.87$ \\
Yolk weight, g & 10 & $21.32 \pm 0.44^{* * *}$ & $15.46 \pm 0.44$ \\
Shell weight, g & 10 & $8.50 \pm 0.17^{* * *}$ & $5.75 \pm 0.17$ \\
Percentage albumen, \% & 10 & $61.35 \pm 0.51^{* * *}$ & $56.19 \pm 0.51$ \\
Percentage yolk, \% & 10 & $27.63 \pm 0.54$ & $31.94 \pm 0.54^{* * *}$ \\
Percentage shell, \% & 10 & $11.02 \pm 0.21$ & $11.87 \pm 0.21^{* *}$ \\
DM in yolk, g/kg & 10 & $515.60 \pm 1.54$ & $516.32 \pm 1.54$ \\
Y (yolk): A (albumen) ratio & 10 & $0.45 \pm 0.01$ & $0.56 \pm 0.01^{* * *}$ \\
\hline
\end{tabular}

***highly significantly $(P \leq 0.001)$ greater than the opposite line, ${ }^{* *}$ significantly $(P \leq 0.01)$ greater than the opposite line

Table 2

Cholesterol content of eggs in lines D+ and D- (LSM \pm SE)

LSQ Mittelwerte \pm Standardfehler des Cholesteringehaltes im Ei bei D+ und D-Linien

\begin{tabular}{lccc}
\hline Cholesterol content & Number of measurements & & Line \\
& & High weight, D+ $^{1}$ & Low weight, D- \\
\hline $\mathrm{mg} / \mathrm{egg}$ & 20 & $341.47 \pm 8.33^{* * *}$ & $212.37 \pm 8.33$ \\
$\mathrm{mg} / \mathrm{g}$ egg & 20 & $4.43 \pm 0.12$ & $4.38 \pm 0.12$ \\
$\mathrm{mg} / \mathrm{g}$ edible egg (albumen + yolk) & 20 & $4.98 \pm 0.13$ & $4.97 \pm 0.13$ \\
$\mathrm{mg} / \mathrm{g}$ yolk & 20 & $16.05 \pm 0.35^{* * *}$ & $13.73 \pm 0.35$ \\
$\mathrm{mg} / \mathrm{g}$ yolk DM & 20 & $31.13 \pm 0.67^{* * *}$ & $26.60 \pm 0.67$ \\
\hline
\end{tabular}

***highly significantly $(P \leq 0.001)$ greater than the $D$ - line, 'Duplicate measurements of cholesterol content were made on each egg. 


\section{Discussion}

According to SIEGEL (1963) egg weight is positively correlated with BW of hens and selection for increased BW has resulted in concomitant increases in egg size. In general, as egg size increases, percent albumen increases and percent yolk decreases (HUSSEIN et al. 1993, AHN et al. 1997, SUK and PARK 2001). In this study, divergent selection for BW resulted in changes in egg size, and the proportions of egg components changed in the expected manner (i.e., percent albumen increased and percent yolk decreased with increased egg size). Significant differences $(P \leq 0.001)$ which were found in the absolute amount of cholesterol per egg could be related to the differences in egg production and egg weight. A survey of the literature suggests a negative relationship between yolk cholesterol level and the rate of egg production. Hens of the D+ line had lower egg production than hens of the D- line. The percent hen-day production of the entire D+ and D- lines was 13.6 and $22.2 \%$, respectively. Measurements were taken in the first 18 wk of egg production. However, we were not able to analyse statistical differences in egg production among the lines from sexual maturity to 49 wk of age because it had been shown that sexual maturity has influenced egg production to a fixed date. Hens of the D+ line reached sexual maturity (laying of the first egg) at 33 wk of age and hens of the $D-$ line at 36 wk of age. When the effect of egg size differences between lines was removed and cholesterol content was expressed as milligrams of cholesterol per gram of egg or milligrams of cholesterol per gram of edible egg no significant differences were found between the two lines (Table 2). Nevertheless, eggs laid by hens of the D+ line contained more $(P \leq 0.001)$ cholesterol per gram of yolk and gram of yolk DM than did the eggs laid by the hens of the $D$ - line. This shift may be explained by the fact that yolk weight to albumen weight ratio was lower $(P \leq 0.001)$ in the $D+$ line than in the $D-$ line (Table 1). The average albumen weight in the $\mathrm{D}+$ line was approximately $74.3 \%$ higher than that in the Dline, whereas yolk weight was only $37.9 \%$ higher. Considering the proportions, eggs from D+ line had $5.16 \%$ more albumen and $4.31 \%$ less yolk than those of the D- line. Therefore, the difference in $\mathrm{Y}$ : A ratio was more the result of differences in albumen proportion than those in yolk proportion. From this data it is concluded that eggs with the larger $Y$ : A ratio do not necessarily contain more cholesterol, which was proposed in the studies of HUSSEIN et al. (1993) and CAMPO (1995). The comparison of eggs from the D- line and eggs from the D+ line showed a reduced $Y$ :A ratio. Nevertheless, they contained more $(P \leq 0.001)$ cholesterol in terms of $\mathrm{mg} / \mathrm{egg}, \mathrm{mg} / \mathrm{g}$ yolk and $\mathrm{mg} / \mathrm{g}$ yolk DM. The deciding factor for yolk cholesterol content (mg/g yolk) was the percentage of yolk amount in the egg. Eggs from the D+ line with higher cholesterol concentration (mg/egg, $\mathrm{mg} / \mathrm{g}$ yolk, $\mathrm{mg} / \mathrm{g}$ yolk DM) were heavier and had a greater absolute and relative amount of albumen, a greater absolute amount of yolk, but a lower relative amount of yolk. The difference in cholesterol content per egg was greater than the difference in yolk weight. The study has revealed that divergent selection did not change the most important cholesterol parameter for table eggs, namely the milligrams of cholesterol per gram of the edible egg. Unfortunately, data on cholesterol concentration and other egg traits were not obtained on the original population (non-selected controls) which is useful in divergent selection experiments because it can detect asymmetric responses. Thus, differences between lines reported herein do not necessarily indicate whether one or both lines changed, nor do they show the direction of the possible change. In conclusion, data from the present study suggest that divergent selection for BW changed egg yolk weight 
and $\mathrm{Y}$ : A ratio. Since the cholesterol content is located almost entirely in the yolk, a change of this type resulted in significant cholesterol concentration $(\mathrm{mg} / \mathrm{g}$ yolk) differences between the two lines. For consumers of market eggs, milligrams of cholesterol per gram of egg or milligrams of cholesterol per gram of edible egg are probably the most relevant expressions of egg cholesterol. In this regard observed differences between high and low weight eggs were small and unimportant.

\section{References}

Ahn U, Kim SM, Shu H (1997) Effect of egg size and strain and age of hens on the solids content of chicken eggs. Poult Sci 76, 914-9

Boehringer-Mannheim (1987) Colorimetric method for the determination of cholesterol in foodstuffs and other materials. Catalogue no. 139050

Campo JL (1995) Comparative yolk cholesterol content in four spanish breeds of hens, an F2 cross, and a white leghorn population. Poult Sci 74, 1061-6

Hargis PS (1988) Modifying egg yolk cholesterol in the domestic fowl - a review. World Poultry Sci J 44, 17-29

Hussein SM, Harms RH, Janky DM (1993) Effect of age on the yolk to albumen ratio in chicken eggs. Poult Sci $72,594-7$

Jiang Z, Sim JS (1991) Egg cholesterol values in relation to the age of laying hens and to egg and yolk weights. Poult Sci 70, 1838-41

Kovacs G, Schmidt J, Husveth F, Dublecz K, Wagner L, Farkas-Zele E (2000) Effect of feed composition on cholesterol content of the table egg. Acta Aliment Hung 29, 25-41

Kritchevsky S, Kritchevsky D (2000) Egg consumption and coronary heart disease: an epidemiological overview. J Am Coll Nutr 19, 549-55

Katz DL, Evans MA, Nawaz H, Njike VY, Chan W, Comerford BP, Hoxley ML (2005) Egg consumption and endothelial function: a randomized controlled crossover trial. Int J Cardiol 99, 65-70

Lee A, Griffin B (2006) Dietary cholesterol, eggs and coronary heart disease risk in perspective. Nutr Bull (British Nutrition Foundation) 31, 21-7

McNamara DJ (2000) The impact of egg limitations on coronary heart disease risk: Do the numbers add up? J Am Coll Nutr 19, 540-8

Pfeuffer M (2001) Physiologic effects of individual fatty acids in animal and human body, with particular attention to coronary heart disease risk modulation. Arch Tierz 44, 89-98

Qureshi Al, Suri FK, Ahmed S, Nasar A, Divani AA, Kirmani JF (2007) Regular egg consumption does not increase the risk of stroke or cardiovascular diseases. Med Sci Monit 13, cr1-8

Sainz F, Gonzales M, Roca P, Alemany P (1983) Physical and chemical nature of eggs from six breeds of domestic fowl. Brit Poultry Sci 24, 301-9

SAS (2001) The SAS system for windows. Release 8.02., Cary, NC, USA

Strakova E, Vitula F, Suchy P, Večerek V, Škaloud J (2001) Cholesterol concentration in yolks and blood plasma in five species of game birds. Arch Tierz 44, 339-43

Suk YO, Park C (2001) Effect of breed and age of hens on the yolk to albumen ratio in two different genetic stock. Poult Sci 80, 855-8

Siegel PB (1963) Selection for body weight at eight weeks of age. 2. correlated responses of feathering, body weights, and reproductive characteristics. Poult Sci 42, 896-905

Weggemans RM, Zock PL, Katan MB (2001) Dietary cholesterol from eggs increases the ratio of total cholesterol to high-density lipoprotein cholesterol in humans: a meta-analysis. Am J Clin Nutr 73, 885-91 
Received 9 September 2009, accepted 17 September 2010.

Corresponding author:

DUŠAN TERČIČ

email: dusan.tercic@bf.uni-lj.si

Department of Animal Science, Groblje 3, 1230 Domžale, Slovenia 